\title{
An Assessment of the Effect of Financial Sector Development on Growth and Unemployment in Nigeria: 1986-2012
}

\author{
M. N. G. Omofa \\ Department of Economics, Kogi State University, Anyigba, Nigeria \\ Email: omofamng@gmail.com
}

How to cite this paper: Omofa, M.N.G. (2017) An Assessment of the Effect of Financial Sector Development on Growth and Unemployment in Nigeria: 1986-2012. Open Journal of Business and Management, 5, 34-50.

http://dx.doi.org/10.4236/ojbm.2017.51004

Received: May 3, 2016

Accepted: December 5, 2016

Published: December 8, 2016

Copyright $\odot 2017$ by author and Scientific Research Publishing Inc. This work is licensed under the Creative Commons Attribution International License (CC BY 4.0).

http://creativecommons.org/licenses/by/4.0/

\begin{abstract}
Parts of the major macroeconomic objectives of any nation are attaining high growth and employment rates. However these constitute major challenges in Nigeria as economic growth has either remained stunted or stagnant and unemployment rate very high. The financial sector is expected to push up the real sector thereby lowering unemployment rate. It is within this supply leading hypothesis that this work is situated. The 3 Stage Least Square method was used in estimating the Growth and Unemployment macroeconomic equations. The results showed that interest rate and exchange rate have effects on growth but only exchange rate was statistically significant. This seems to suggest that there is a disconnection between the Nigerian money market and the real sector. However interest rate and exchange rate were significant in influencing the rate of unemployment in Nigeria. The goodness of fits for each of the two equations was high. The simulation results showed that the shock in the financial sector has serious implications for the economic growth and unemployment. The work therefore suggests that interest rate and exchange rate should not be left absolutely to the dictate of the market forces. Occasionally government should intervene in these markets as the time requires.
\end{abstract}

\section{Keywords}

Economic Growth, Financial Sector, Unemployment, Money Market, Capital Market, Foreign Exchange Market, Simulations, 3 Stage Least Square, Interest Rate and Exchange Rate

\section{Introduction}

The behavior of the economy as a whole and the determination of broad economic aggregates such as national income or national product and unemployment, etc. fall within the domain of macroeconomic study. It also deals with the forces or factors which determine the levels of these aggregates as well as the structure or components of 
some of these aggregates. Thus the broad macroeconomic objectives include maintenance of full employment, achievement of high, rapid and sustainable economic growth, etc. Thus macroeconomic stability becomes a barometer through which the health of the economy can be measured.

One of the most difficult questions in macroeconomics is: what are the shocks that cause these macroeconomic fluctuations? Longstanding suspects are fiscal policy, oil price shocks, and monetary policy. To this list Prescott (1986) [1] added technology shocks, and argued that they "account for more than half the fluctuations in the postwar period with a best point estimate near 75\%". Many studies (Bernanke et al., 1999 [2]; Dixit and Stidlitz 1977 [3]; Altigetal 2004 [4]; Galietal 2004 [5]; and Smets and Walters 2003 [6]), even with the recent introduction of technology factor, emphasized the role of monetary factors in influencing the real sector development. Even though technology shocks continued to be important, monetary forces play a significant role in shaping the economy's response to technology shocks. Thus, the stability of the financial sector that would facilitate not only short term but also long term investment becomes essential ingredients for economic growth and employment.

In Nigeria, macroeconomic instability has continued to be a major problem as reality on ground shows that her macroeconomic objectives have been quite elusive despite the reform policies of government thereby making the economy highly susceptible to general domestic and external shocks. This is why according to Nwaogwugwu (2010) [7], the macroeconomic performance in Nigeria over the past three decades has been both unsatisfactory and disappointing because economic growth has been stunted and often accompanied by sharp declines in rates of investment, consistent high fiscal deficits and high rate of inflation. Domestic saving rates have fallen dramatically, thereby contributing to unsustainable external payment positions. In attempting to correct external imbalances through reduction in aggregate demand, government has further compressed investment expenditures, completing the vicious circle of sluggish growth, high unemployment rate and declining investment and savings rates.

A cursory look at the real sector of the economy shows that the performance of the real sector has not been very encouraging over the years. For example, the growth rate of the agricultural sector was $5.8 \%$ between 1990 and 1993 but declined to 3.5\% between 1997 and 1998 and further declined to 1.8\% during the period 1999 to 2001. The total value of agriculture which stood at N4, 7731 billion in 2005 decreased to N1936 billion in 2009 nominal value. The poor growth of this sector has been disturbing, given the fact that it employs about 70\% of the nation's labor force (CBN 2009) [8].

The performance of the industrial sector has also remained unsatisfactory. Available data show that between 1990 and 1992, average growth in the sector stood at $2.1 \%$ while between 1993 and 1995, growth was 1.3\%. The slow growth in industrial production was mirrored in the sluggish growth of the key sub-sectors of the economy. For the period 1993 to 1995 , the average growth of manufacturing sector stood at $8.4 \%$, mining at $3.2 \%$ and electricity at $3.1 \%$. The mining sub-sector grew by $7.4 \%$ during the period 1999 and 2001, perhaps as a result of increased activity in the solid minerals sub-sector (CBN 2009) [8].

In 1987, the Federal government of Nigeria commenced an extensive reform of the 
financial system as part of a Structural Adjustment Programme (SAP). The reforms in the capital, money and foreign exchange markets involved liberalizing interest and exchange rates, promoting a market-based system of credit allocation, flexible exchange rate system for naira, enhancing competition and efficiency in the financial system as well as strengthening the regulatory and supervisory framework of the financial system. However recent and current development in the economy has made it not clear if the reforms have achieved the desired results.

With SAP in 1986 and the consequent expansionary fiscal and monetary policies of the federal government, money supply jumped from $1.2 \%$ in 1986 to $60.4 \%$ in 1992 before declining to $18.4 \%$ in 1998 . By year 2000 it increased by $62.2 \%$ before declining to 29.5\% in 2003 and 6.3\% in 2007 (CBN Annual Statement 2009) [8]. The overall increase in money supply usually, lead to a situation of too much money chasing too few goods making prices of goods and services to equally increase. The prime lending rate equally rose sharply from $9.25 \%$ in 1985 to $36.09 \%$ in 1993 before declining to $18.4 \%$ in 1998 and subsequently to $16.94 \%$ in 2007 (CBN Annual Statement 2009) [8]. The increase in the prime lending rate resulted in high costs of borrowing to the real sector thereby further reinforcing the high cost of production and the unit price of goods and services. From the foregoing one can say that the response of the real sector to policy changes has not been very encouraging. For instance, the real Gross Domestic Product (GDP) at 1990 prices was negative for the period 1982 to 1984 while it turned positive (2.45\%) in 1986. Apart from 1990 and 2002 when real GDP at 1990 prices were reasonably high (13.02\% \& and $21.35 \%$ respectively) they became low and even declined in other years. For example, in 2003 it declined to $10.23 \%$ and further declined to $6.51 \%$ in 2005 . By 2007 real GDP growth was $6.44 \%$ only to marginally increase to $6.67 \%$ in 2009 (CBN 2009) [8]. From 2009 to 2012, the real GDP growth rate was less than $0.5 \%$. Over the entire period of 1986 to 2012, the economy witnessed a slow growth (Omofa 2014) [9].

Unemployment rate which stood at 5.8\% in 1986 grew to $14.8 \%$ in 2003 . It further went up to $23.9 \%$ in 2010 before declining to about $16.4 \%$ in 2011 . By 2012 it went up to about $17.2 \%$ (Omofa 2014) [9]. These are parts of the disappointing performance of the Nigeria economy that led to the financial sector reforms because the sector was regarded by policy makers as an obstacle to the overall macroeconomic development and stability. However, there is no empirical evidence to confirm this.

It is therefore in the light of the above that it becomes imperative to assess the impact of financial sector development on economic growth and unemployment in Nigeria.

This paper is divided into five sections. The preceding section is introduction, while section two contains theoretical discuss and literature review. Section three contains methodology while section four discusses empirical results. Section five summarizes, recommends and draws its conclusion.

\section{Theoretical Nexus and Literature Discussion}

The centrality of financial sector development to economic growth has not been doubted. Financial sector development affects economic growth in five ways; by lowering transaction cost and thereby encouraging deposits; reducing risk of uncertainty associated with investment projects; providing information on borrower to savers; pro- 
viding corporate governance that helps to maximize firms value thereby improving allocation of resources; and encouraging specialization through its exchange function which lower financial transactions.

However there are two theories that discuss the relationship between the real sector growth and financial sector. These theories are the supply leading hypothesis and the demand following hypothesis.

\subsection{Supply Leading Hypothesis}

The supply-leading concept notes that the development of financial sector induces growth in the real sector through savings collection, project valuation, risk management, management control and financial institutions. Thus this can contribute to technological innovations and lead to improvement in the real sector. Moreover, according to the supply leading hypothesis, financial sector development leads to transfer of resources from the traditional sector to the modern sector and promotes and stimulates an entrepreneurial response in these modern sectors (Roger et al. 2005) [10]. Thus this approach represents the initial stage of economic development as it supplies the major channel through which economic activities take place.

Mohammed (2004) [11] summarized Nwani (1973) [12] argument that a fully analyzed supply-leading approach in the development of financial institutions and their services may emphasize the following;

a) Monetization of the economy may be hastened and the money civilization process could be deepened.

b) Economic planning and development may be aided by the channeling of investible funds to established priorities.

c) Economic development is not always a slow evolving process but can be stimulated by more financial institutions.

d) Enables a nation to break the chains of total external control, and

e) Fair and greater competition may be promoted.

\subsection{Demand-Following Hypothesis}

The demand-following concept shows that the real sector can stimulate the development of financial intermediation. According to this school of thought, it is believed that real sector growth and stability lead to increase in the demand for financial services which in turn encourages the creation of financial intermediaries and financial stability (Nwani 1973 [12], Gurley and Shaw 1976 [13]; Rogers et al. 2005 [10]). They underscored the importance of attaining macroeconomic stability prior to financial deregulation. This according to them is because high and unstable inflation often increases the demand for financial deregulation, but this might trigger further increases in inflation especially if fiscal deficits are large and the exchange rate is depreciating rapidly. As the government finances its deficits through money creation the higher interest rates resulting from the financial liberalization would reduce government revenue from money creation: with a given budget, this would further increase inflation.

Mohammed (2004) [14] summarized this view that, the demand-following approach could result in the following; 
1) Increasing advantages to the colonial powers and will solidify the competitive advantage of foreign entrepreneurs. We may also add here that, this approach may result in the creation of oligopolistic structure of the banking industry in which only very few banks control a large proportion of the activities of the industry.

2) A conservation form of financial development, which may slow down the pace of economic development, and

3) Discrimination against borrowers whether in the agricultural, commercial or manufacturing sectors and leads to the development of monopoly trade.

Thus the issue of financial deregulation has remained controversial for the developing countries. Schmidt-Hebbel and Serven (2002) [15] contend that financial liberalization is not risk free and should be carefully implemented to attain its benefit. According to them, an excessive rapid financial reform often leads to financial crises. This risks they maintained increase significantly in the absence of prudential guidelines and strong supervision of banks and other liberalized capital market segments. The underlying framework for this paper is the supply leading hypothesis which represents an opportunity to induce improvements in macroeconomic growth and stability by the creation or supply of financial institutions ahead of the demand for them (financial sector development). Put in another way, financial markets can make a difference on economic decision-making, and the allocation of resources, by addressing information problems and then lead to a positive result on both the volume and pattern of investment, as well as productivity of physical and human capital. These are important channels for macroeconomic growth and stability.

The adoption of the supply leading hypothesis is predicated on two issues. One, is the fact that, the studies supporting demand-following hypothesis is fairly limited (Jadamba et al. 2008) [16]; two, that it explains the policy direction of Nigeria since 1996. Aigbokhan (1996) [17] described the different financial sector policy regimes along supply leading and demand following hypotheses. He argued that the deregulation which started in 1986 could be said to reflect belief in supply-leading hypothesis while he considered the reversal of the deregulation in 1994 with return to what government referred to as "managed deregulation" that is administratively determined interest rate and a halt to liberal bank licensing, suggested a weakening of the belief and reflects a belief in the "demand-following" hypothesis. Aigbokhan (1996) [17], also highlighted the government's return to full deregulation of the financial sector in October 1996 as reversal to the belief of the supply-leading hypothesis.

There is a considerable amount of empirical studies undertaken to investigate the relationship between financial markets and economic growth. The first work in this area was that by Goldsmith (1969) [18] who examined the relationship between economic growth and aggregate measures of how well the financial system functions. He used the value of financial intermediary assets divided by GNP to assess financial development under simplistic assumption that the size of the financial system was positively correlated with the provision and quality of financial services. He collected data from 35 countries covering the periods 1950-1963. He revealed that a relationship could be observed between economic and financial development if periods of several decades were considered, and that there were indications in the few countries for which the data were 
available that periods of rapid economic growth was accompanied (though not without exception), by an above-average rate of financial development.

Ahmed (2011) [19] examined the macroeconomic effects of financial liberalization in Pakistan from 1961-2002 using annual time series data. He developed a four equations macro model comprising of savings, demand for money, investment and growth. His chow test results showed that the parameters were not constant during the period under review and this made him to split the data in on savings, into five (5) groups. His study concluded that most of the financial liberalization indicators do not show any significant impact on savings, investment and economic growth. However, Ahmed's study was focused on Pakistan which does not have the same economic history cum reform processes.

The above literature review provided cross-country analysis in some cases while in some it has to do with foreign countries. The literature therefore merely explain situations in both developing and developed economy as the case may be but did not give adequate insights into the real world situation as it affects Nigeria. Moreso, they made used of VAR and discriminate analysis.

Ikhide et al. (2001) [20] analyzed financial sector reform, macroeconomic instability and the order of economic liberalization in Nigeria using capital, assets, management, earnings and liquidity (CAMEL) analysis. He identified sequencing errors in the liberalization that has contributed to financial crises which made very many banks weak and insolvent until the late 1990s. The results showed that there is a significant variation in pre and post-reform performances of the banks, though more prominent for the distressed banks. However, the direction of change is not indicated.

Olofin and Udoma (2006) [21] developed 3 structural equations to capture the relationship between financial structures and various economic aggregates. His major variables upon which real GDP depended were banking sector credit, domestic investment, exchange rate, interest rate, money supply and price level. He estimated the equations using 3SLS and the result showed that the financial structure was indirectly related to aggregate domestic investment and real GDP per capita through its impact on banking sector domestic credit. The model tracked the historical data well. Also the model perform well using Theil test. However the model is small and narrow in scope and in content. They were concerned majorly with the structure of the sector. The period covered was 1970-2005 which made the model not to be able to capture more recent developments in the Nigerian financial sector.

Ajayi and Kolapo (2013) [22] investigate the effect of banking sector reforms on economic growth of Nigeria over the period 1986 to 2010. The study adopts multiple regression analysis of ordinary least square and descriptive analysis in establishing the relationship between gross domestic product and interest rate, exchange rate, cash reserve ratio, total asset and loan and advances. The study showed that total asset, cash reserve ratio and interest rate has a significant impact on gross domestic product while exchange rate and loans and advances has no significant impact on gross domestic products. However this study concentrated on banking sector (money market) only at the neglect of other non-banking sector such as the capital market and the foreign exchange market. Besides, its main focus is on economic growth. A study of this magni- 
tude should not be a single equation analysis.

Umejiaku (2011) [23] gave a graphical illustration of the impact of financial sector reform in Nigeria on some financial sector and real sector variables such as the ratio of broad money stock to income, ratio of bank deposits to GDP, ratio of private domestic credit to income, the stock market value to GDP, interest rate, exchange rate, ETC. The study showed that most of the variables used portrayed a failure in achieving the desired results. This according to her put Nigeria in the League of Nations that failed to achieve its objectives. A graphical exposition would not bring out clearly the natur of relationship nor measure the extent of the impact of these financial sector and real sector variables on the economy.

Sulaiman, Oke and Azeez (2012) [24] investigate the effect of financial liberalization on economic growth of developing countries using Nigeria as a case study from 1987 to 2009. The study developed a single equation model where GDP was made the dependent variable and the following macroeconomic variables: lending rate, exchange rate, inflation rate, financial deepening and degree of openness as its financial liberalization indices. Using Annual data, they employed Johansen Co-integration test and the Error Correction Mechanism (ECM). The results from the co-integration showed the existence of long-run equilibrium relationship among the variables and co-integrating equations at $5 \%$ significance level. Also, the ECM showed a very high coefficient of multiple determination $\left(\mathrm{R}^{2}\right)$ in both the over-parameterized model $(95 \%)$ and the parsimonious model (91\%). However, a critical analysis of the effect of financial sector development on Nigeria economy requires a more detailed diagnostic analysis than a single equation model.

\section{Methodology and Model Specification}

This paper made use of 3 stage Least Square method (3SLS) to estimate the effect of financial sector development on economic growth and unemployment. The 3SLS make use of information of all pre-determined variables in the model and estimates the structural equations simultaneously. The method of incorporating the predeterminedvariable information into each structural equation is to multiply the predetermined variables throughout each structural equation. However this transformation will lead to a possible non-constant-error variance for each structural equation. In order to correct this situation, when we estimate the model by the 2SLS, we use the residuals from it as weighting factor and perform the weighted regression to correct for possible heteroscedasticity (Christ, 1968 [25]; Iyoha, 2004 [26]).

Also the 3SLS estimates all the structural coefficients simultaneously. It is therefore a full information method since the complete specification of the model is taken into account explicitly. No information is discarded or ignored. As expected, therefore, a system estimator which is a method that uses more information will yield estimates that are consistent and efficient. Since the ability of a model to simulate and forecast well also depend on the particular method used to estimate the models coefficients (Fair 1973; 261-277) [27].

Simulation experiments involving three scenarios which form the base case directions of national policies (contractionary policies) are conducted and would be ana- 
lyzed as follows:

Scenario I: A 10\% decrease in Money supply (M2).

Scenario II: A 10\% decrease in rate of interest (ROT).

Scenario III: A 10\% decrease in market capitalization (MCAP).

Scenario IV: A 10\% decrease in exchange rate (EXR).

Finally the paper adopted the Theil's test of inequality coefficient and its decomposition into bias, variance and covariance. The Theil's inequality coefficient always lies between zero (0) and one (1), where zero indicates a perfect fit and one (1) otherwise. While bias proportion shows how far the mean of the forecast is from the mean of the actual series, the variance proportion tells us how far the variation of the forecast is from the variation of the actual series. The covariance proportion measures the remaining unsystematic forecasting errors. Note that the bias, variance and covariance proportions add up to one (1). This was used by Olofin and Udoma (2006) [21].

\section{Model Specification}

This dissertation adopted a simple Keynesian variant model of national income in which the Keynesian national income identity of the four-sector economy is given by;

$$
Y=C+I+G+(X-M)
$$

Equation (1.1) was modified by Iyioha (1998) [28] where he made Gross Domestic Product (GDP) from the expenditure approach to equal national output from the income approach and equal to Gross Domestic Output by the way this income is disposed. This is because the national income and product accounts offers explanations of the key aggregates such as Aggregate production (GDP), Consumption, Investment, Government expenditures, Net export etc. which are central to macroeconomic analysis. According to him,

$$
C+I+G+(X-M)=G D P=C+S+T+R f
$$

where

$$
\begin{aligned}
& C=\text { Aggregate consumption } \\
& I=\text { Aggregate investment } \\
& G=\text { Aggregate Government expenditure and } \\
& X=\text { Export } \\
& M=\text { Import } \\
& G D P=\text { Gross Domestic Product } \\
& S=\text { Aggregate savings } \\
& T=\text { Taxes } \\
& R f=\text { Transfer payments. }
\end{aligned}
$$

The first and the third sides of the equations give us the basic equation of identity for the output of a nation's economy.

The Iyioha variant was further modified from Equation (1.2) above, in which the (GDP) aggregate production function is a behavioural equation in which the monetarist considered to be influenced by the monetary factors. They posited a stable but not precise relationship between the growth rates of money and nominal GNP. If money balances grow more rapidly as a result of excess money supply in the economy in relation 
to income the people wish, they will attempt to spend the excess and if GDP could not grow to match demand, then it would translate to rise in prices. On the other hand if money grows too slowly in relation to income, people would build up their cash balances by reducing spending, which would result in a slowing of income growth and rising unemployment.

High rate of interest (ROT) raises cost of borrowing for investment and hence reduces investments. Investment generates employment opportunities thus increasing the productive capacity of an economy. Therefore high rate of interest does not encourage investment and output due to high cost of borrowing and production as it makes investment poor and employment stifled.

The domestic production of the Nigerian economy is hinged on foreign inputs and imported machineries and equipments. With scarcity of foreign exchange (EXR) and the devaluation of naira, the domestic cost of production would rise due to high cost of imported inputs needed for the domestic production. High cost of production may require cutting down of production hence escalating the unemployment problem.

Other non financial determinants of GNP and UNEMP include personal consumption expenditures, government expenditures, net export and capacity utilization rate.

Therefore the Gross Domestic Product (GDP) and the Unemployment (UNEMP) equations are specified as follow;

$$
\begin{aligned}
& G D P=C_{1}+C_{2} M S+C_{3} R O T+C_{4} E X R+C_{5} G E X+C_{6} N E X \\
& +C_{7} C U R+C_{8} U N E M P_{t-1}+U_{t}
\end{aligned}
$$

and

$$
U N E M P=C_{9}+C_{10} R O T+C_{11} M S+C_{12} E X R+C_{13} G D P+C_{14} P C E+U_{t}
$$

where, $G D P=$ Gross Domestic Product

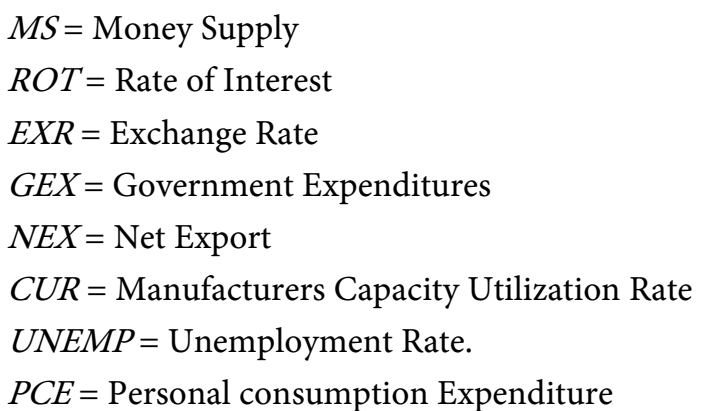

Equation (1.3) and Equation (1.4) are the equations estimated in this paper.

\section{Empirical Results}

The results of the estimate of the 3SLS are hereby presented in the Table 1.

The empirical results are for two equations: The first equation is Gross domestic product (GDP) which is Equation (1.5) while the second equation is Unemployment (UNEMP) which is Equation (1.6). From Table 1, it was found out that, with the exception of exchange rate (EXR) all the financial sector variables used (ROT, MS) were wrongly signed for the GDP equation. As exchange rate depreciate, it stimulates domestic production because it makes domestic goods cheaper at the international market therefore stimulating international demand for the domestic products. Its coefficient 
Table 1. Empirical results.

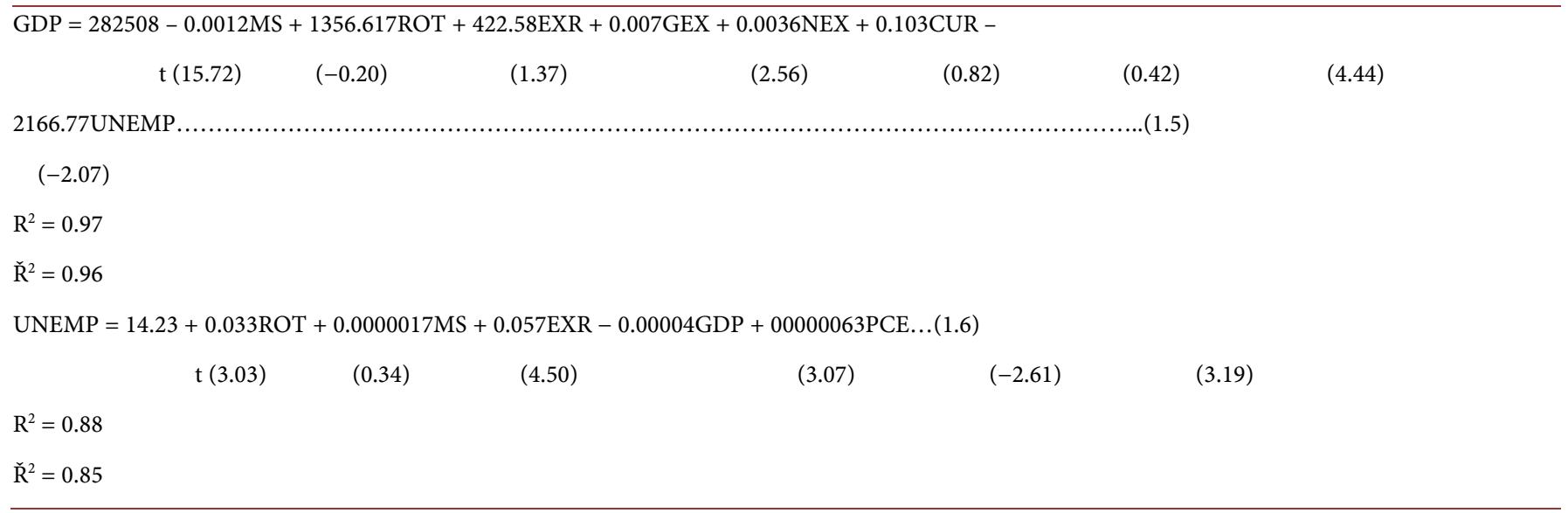

was high and it was statistically significant. The wrong signs of the ROT and MS are not unconnected with the level of development in the money market. This suggested that the Nigeria financial sector is not highly developed as it seemed and that there was a disconnection between the Nigerian financial sector and the real sector. This tends to support the Keyensian argument that monetary policy may not have serious effect on the real sector. Other non-financial sector variables were correctly signed. However, only capacity utilization (CUR) and unemployment (UNEMP) have significant impact on GDP. The $\mathrm{R}^{2}$ and $\check{\mathrm{R}}^{2}$ were 0.97 and 0.96 showing a high goodness of fit as this indicates that about $97 \%$ of the variation in GDP is explained by the variations in the independent variables.

For the Unemployment equation (Equation 1.6), all the financial sector variables used were correctly signed except Money supply (MS). This portended the disconnect between the real sector and the financial sector as discussed above. Rate of interest (ROT) and exchange rate (EXR) were correctly signed. High interest rate implied increase in cost of borrowing for investment purpose and this raised the cost of production making labour to be laid off compounding the problem of unemployment. Devaluation of local currency for an import dependent economy such as Nigeria, where locally manufactured goods depends on imported inputs stifled domestic production thereby leading to unemployment problem. Statistically significant among these financial variables were Money supply (MS) and exchange rate (EXR). Other non-financial sector variables were GDP and PCE, they were correctly signed and statistically significant. However, all the coefficients of the equations were low. The $\mathrm{R}^{2}$ and $\breve{\mathrm{R}}^{2}$ were 0.88 and 0.85 respectively. These showed that the model has a high goodness of fit and that about $88 \%$ of the variations in UNEMP were explained by the independent variables.

The policy implication of the equations can be deduced from the results. The first equation is gross domestic product. The financial sector variables that contributed positively to GDP are ROT and EXR. However it is only EXR that is of statistical significance but they have low coefficients. Unemployment is the second equation in this bloc. ROT, MS and EXR have positive relationship with unemployment in Nigeria over the period of study. However it is MS and EXR that have significant impact.

The strength of relationship in causality is determined by the strength of fit or esti- 
mated data series of the endogenous variables. As shown in Table 1, the goodness of fit statistics is tight in the two equations. The $\mathrm{R}^{2}$ ranged from the minimum 0.83 to 0.98 showing that at least $83 \%$ of the variation in the endogenous variable (Unemployment) is explained by the variations in the exogenous variables (financial sector variables) while for GDP it was about $98 \%$. Even for the adjusted $\mathrm{R}^{2}$ it was 0.78 for Unemployment and for GDP it was 0.97 indicating that there is not much difference between the $\mathrm{R}^{2}$ and the adjusted $\mathrm{R}^{2}$.

These results PROVIDE the basis to REJECT the Null Hypothesis and ACCEPT the alternative hypothesis that developments in the financial sector have significant impact on growth and unemployment in Nigeria.

The Theil's inequality coefficients results are presented in the Table 2 above. The Theil's inequality coefficients were used to test the forecasting power of the models. It is normal that the Theil's inequality coefficients should lie between zero and one. The decision rule is that for a model to have a good forecasting power, the Theil's inequality should be less than unity. The results show that the worst Theil's coefficient (0.1) is well close to zero. This implies that the models have a very good forecasting power.

Furthermore, the Theil's coefficients analysis is required to evaluate the model's ability to replicate turning points. The partial inequality coefficients are standard indices in this measurement. As expected, the partial inequality coefficients were used to trace the size of the error between the predictions (simulated values and realizations in the means, variance and covariance of the estimated models. The results of the bias and the variance proportions of the error between the predicted and estimated values in Table 2 show that the difference between the means of the simulated values and the means of the actual data series (bias proportion) and between the variance of the simulated values and the variance of the actual data series (variance proportion) are almost zero in the two equations. This implies that the models have very strong ability to replicate turning points in the actual data series with respect to each of the macroeconomic variables. The results of the covariance proportion which measures how predicted or forecasted values are closely correlated with the actual values of the growth and unemployment variables are very close to unity. These show that the forecasted values are closely correlated to the actual values.

The simulation results for each financial market showed that:

(a) Money market

1) A decrease in money supply (MS) by $10 \%$ will make GDP to increase by $10.36 \%$ but reduces UNEMP by $6.8 \%$ while an increase in money supply (MS) by $10 \%$ will reduce GDP by $4.3 \%$ but increase UNEMP by $1.27 \%$.

2) A decrease in rate of interest (ROT) by $10 \%$ will make GDP to decrease by $0.19 \%$ and UNEMP to increase by $0.12 \%$ while an increase in rate of interest (ROT) by $10 \%$

Table 2. Theil inequality coefficients.

\begin{tabular}{ccccc}
\hline Equations & Theil's Inequality Coefficient & Bias Proportion & Variance Proportion & Covariance Proportion \\
\hline GDP & 0.024409 & 0.000000 & 0.006091 & 0.993909 \\
UNEMP & 0.105588 & 0.000000 & 0.031366 & 0.968634 \\
\hline
\end{tabular}


will increase GDP by $0.02 \%$ and UNEMP to decrease by $0.12 \%$.

\section{(b) Capital market}

1) A decrease in market capitalization (MCAP) by $10 \%$ will increase GDP by $1.9 \%$ and UNEMP will reduce by $2.31 \%$ while and increase in market capitalization (MCAP) by $10 \%$ will make GDP to decrease by $1.87 \%$ and UNEMP to increase by $2.36 \%$.

\section{(c) Foreign exchange market}

1) A decrease in exchange rate (EXR) by $10 \%$ will make GDP to increase by $0.61 \%$ and UNEMP to increase by $3.08 \%$ while an increase in exchange rate (EXR) by $10 \%$ will make GDP to increase by $0.02 \%$ and UNEMP to decrease by $0.12 \%$.

With the outcome of the policy simulation exercise, it is imperative that some measures of control be pursued on money supply, interest rate and exchange rate. This implies that the federal government should not print or release money into the economy as she likes. It called for fiscal discipline on the part of government. Also, the federal government should intervene in the determination of interest rate and exchange rate when necessary and should not be left completely to the forces of the market.

\section{Summary, Conclusion and Recommendations}

This paper examined how the instability in the money market, capital market and foreign exchange market affects economic growth and unemployment in Nigeria. The study found that money supply (MS) interest rate (ROT) and exchange rate (EXR) had positive impact on gross domestic product (GDP) for the period of study.

Also, money supply (MS) and exchange rate (EXR) had positive impact on unemployment. Only interest rate (ROT) is the financial sector variable that had a reducing effect on unemployment over the study period.

The simulation experiments showed that substantial increase was noticed in GDP when money supply was changed by $10 \%$ but reduced minimally when interest rate was changed by $10 \%$. When market capitalization was changed by $10 \%$ unemployment increased moderately. Finally, when exchange rate was changed by $10 \%$, unemployment increased moderately.

From the findings in the study, it is concluded that financial markets had both positive and negative effects on GDP and Unemployment. However, it must be stressed that the growth of the financial markets had marginal effects on economic growth in Nigeria and that exchange rate depreciation coupled with interest rate deregulation hindered the realization of the macroeconomic objectives of increasing growth and reducing unemployment. However, it was difficult to establish which of the financial markets had the greatest impact on economic growth.

It is therefore recommended that the rate of interest should be lowered. This would make domestic credit available and investment is encouraged thereby improving activities in the money market which will make the frontier of the economy to expand. However, the complete deregulation of interest rate should not be pursued but rather guided deregulation through the manipulation of the minimum rediscount rate by the Central Bank of Nigeria (CBN).

Furthermore, the foreign exchange conditions that would make Naira appreciate should be put in place. The total subjection of the foreign exchange determination of 
Naira to the dictates of the market should be looked into. Government should intervene when necessary and abstain when the market improves; thus there should be guided deregulation of the foreign exchange market.

Finally, activities in the capital market should be encouraged. The three tiers of government should be encouraged in the use of development stocks for their long term development objectives. This would even expand activities in the capital market of Nigeria thus having multiplier effect on the overall economy.

\section{References}

[1] Prescott, E.C. (1986) Theory Ahead of Business Cycle Measurement. In: Brunner, K. and Meter, A.H., Eds., Real Business Cycle, Real Exchange Rates and Actual Policies, Carnegie-Rochester Conferences Series on Public Policy 25.

[2] Bernanke, B., Gertler, M. and Gilchrist, S. (1999) The Financial Accelerator in a Quantitative Business Cycle Framework. In: Taylor, J.B. and Woodford, M., Eds., Handbook of Macroeconomics, Elsevier Science, North-Holland, Amsterdam, New York and Oxford, 1341-1393.

[3] Dixit, A. and Stiglitz, J. (1977) Monopolistic Competition and Optimum Product Diversity. American Economic Review, 67, 297-308.

[4] Altig, D., Christiano, L.J., Eichenbaum, M. and Linde, J. (2004) Firm-Specific Capital, Nominal Rigidities and the Business Cycle. Mimeo, Northwestern University, Evanston, IL.

[5] Gali, J., Lopez-Salido, D. and Valles, J. (2004) Technology Shocks and Monetary Policy: Assessing the Fed's Performance. Journal of Monetary Economics, 50, 723-743. https://doi.org/10.1016/S0304-3932(03)00037-0

[6] Smets, F. and Wouters, R. (2003) An Estimated Dynamic Stochastic General Equilibrium Model of the Euro Area. Journal of the European Economic Association, 1, 1123-1175. https://doi.org/10.1162/154247603770383415

[7] Nwaogwugwu, I.C. (2010) An Evaluation of Macroeconomic Performance in Nigeria Between 1960 and 2009. In: Olurode, L., Ed., Reflections on a Decade of Democratization in Nigeria, FES. Abuja, Nigeria.

[8] CBN (2009) Central Bank of Nigeria Statistical Bulletin. CBN, Abuja.

[9] Omofa, M.N.G. (2014) The Effects of Financial Sector Development on Some Selected Macroeconomic Variables in Nigeria, 1986-2012. Unpublished PhD Dissertation, Ahmadu Bello University, Zaria.

[10] Roger, B.A., Pierre, G.J. and Edoh, K.A. (2005) Financial Intermediation and Economic Growth: Evidence from Western Africa. Journal of Applied Financial Economics, 15, 777790. https://doi.org/10.1080/09603100500108030

[11] Mohammed, S.J. (2004) An Evaluation of the Contribution of Financial Growth to Economic Growth, 1975-1988. Unpublished MSc Thesis, Ahmadu Bello University, Zaria.

[12] Nwani, D.C. (1973) The Role of Monetary and Financial Institutions in Economic Development in Nigeria, 1800-1970. Unpublished PhD Thesis, Department of Economics, Florida State University, Tallahassee.

[13] Gurley, J.G. and Shaw, R. (1976) Financial Structure and Economic Development. Journal of Economic Development and Cultural Change, 15, 257-268. https://doi.org/10.1086/450226

[14] Mohammed, S.J. (2004) An Evaluation of the Contribution of Financial Growth to Economic Growth, 1975-1988. Unpublished MSc Thesis, Ahmadu Bello University, Zaria.

[15] Schmidt-Hebbel, K. and Serven, L. (2002) Financial Liberalization, Savings and Growth. 
Proceedings of the Conference on Macroeconomic Stability, Financial Markets and Economic Development, Mexico, 12-13 November 2002, 1-31.

[16] Jadamba, U. and Terukazu, S. (2008) Nexus between Financial Sector Development and Economic Growth; An Empirical Analysis of 112 Countries. International Research Journal of Finance and Economics, 30, 88-94

[17] Ikhide, S.I. and Alawode, A.A. (2001) Financial Sector Reform, Macroeconomic Instability and the Order of Economic Liberalization: The Evidence from Nigeria. AERC Research Paper 112, Nairobi, Kenya.

[18] Goldsmith, J. (1969) Financial Structure and Development. Yale University Press, New Heaven.

[19] Ahmed, M.K. (2011) Macroeconomic Effects of Financial Liberalization in Pakistan: An Assessment. International Journal of Economic and Finance, 3, 16-42.

[20] Ikhide, S.I. and Alawode, A.A. (2001) Financial Sector Reform, Macroeconomic Instability and the Order of Economic Liberalization: The Evidence from Nigeria. AERC Research Paper 112, Nairobi, Kenya.

[21] Olofin, S.O. and Udoma, J.A. (2006) Financial Structure and Economic Growth in Nigeria; A Macroeconometric Approach. JEL Classification Number: C51, E44, E47.

[22] Ajayi, I.B. and Kolapo, F.T. (2013) The Effects of Banking Sector Reforms on Nigerian Economy. International Journal of Innovative Research and Development, 2, 130-140.

[23] Umejiaku Rose Ifeoma (2011) Financial Reform and Financial Development in Nigeria: A Graphical Analysis. African Research Review, 5, 247-260. www.ajol.info

[24] Sulaiman, I.A., Oke, M.O. and Azeez, B.A. (2012) Effect of Financial Liberalization on Economic Growth in Developing countries: The Nigerian Experience. International Journal of Economic and Management Sciences, 1, 16-28.

[25] Christ, C. (1968) Econometric Models and Methods. Wiley, New York.

[26] Iyoha, M.A. (2004) Applied Econometrics. Revised Edition, Mindex Publishing, Benin City.

[27] Fair, R.C. (1973) A Comparison of Alternative Estimators of Macroeconomic Model. International Economic Review, 27, 207-221.

[28] Iyoha, M.A. (1998) Macroeconomics for a Developing World. Miyo Educational Publisher, Benin City. 


\section{Appendix}

Tracking of Actual and Simulated Values

Tracking of Simulated Values of Money Supply
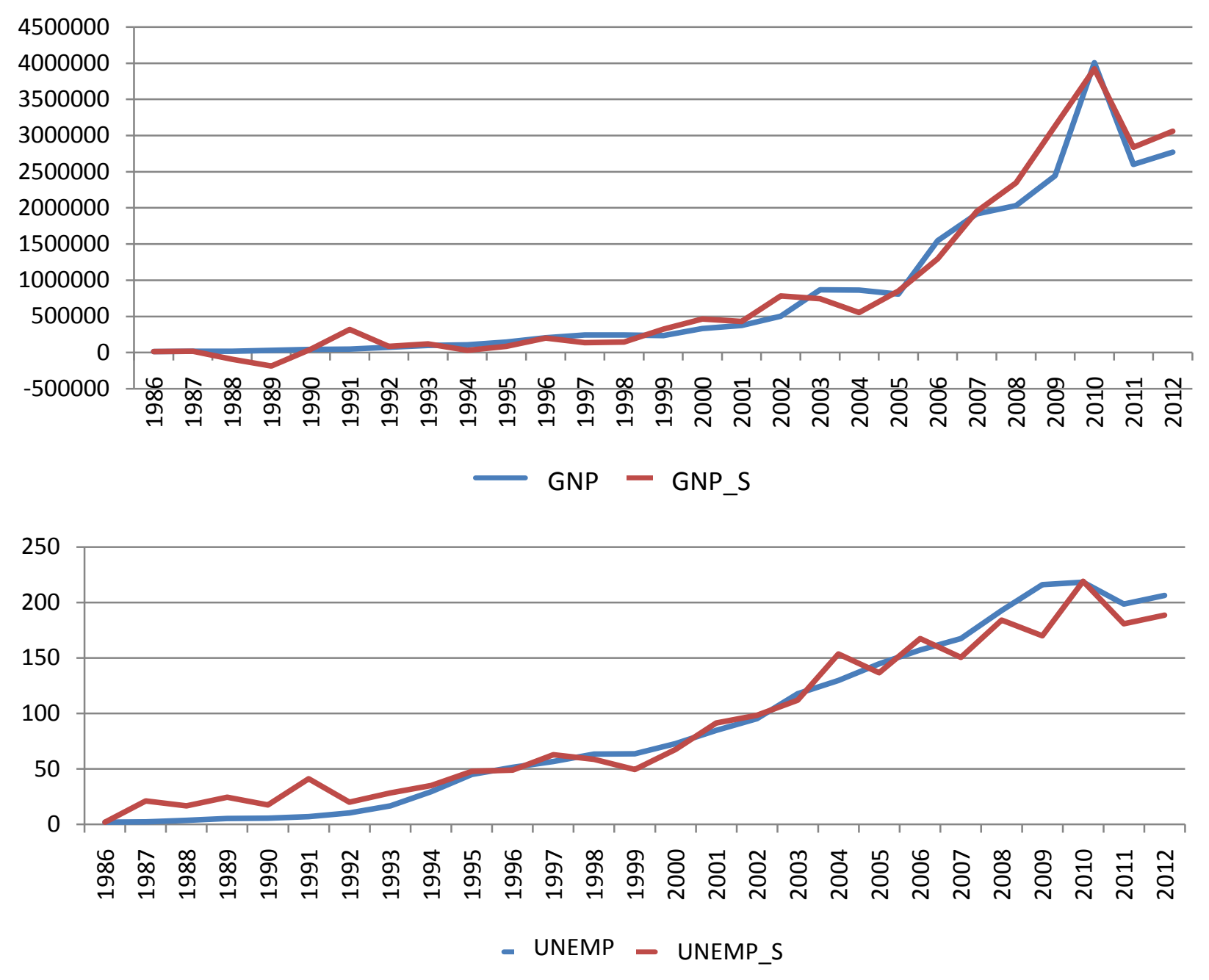

Tracking of Simulated Value of ROT

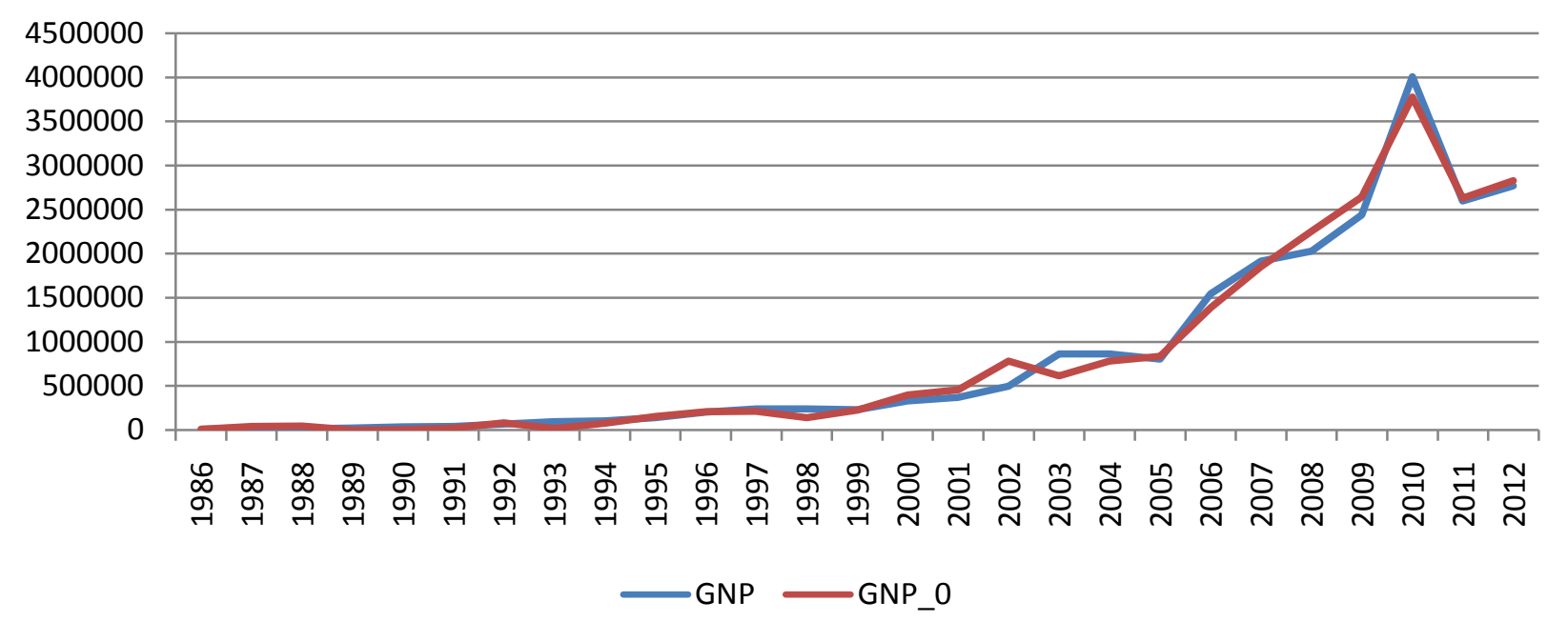




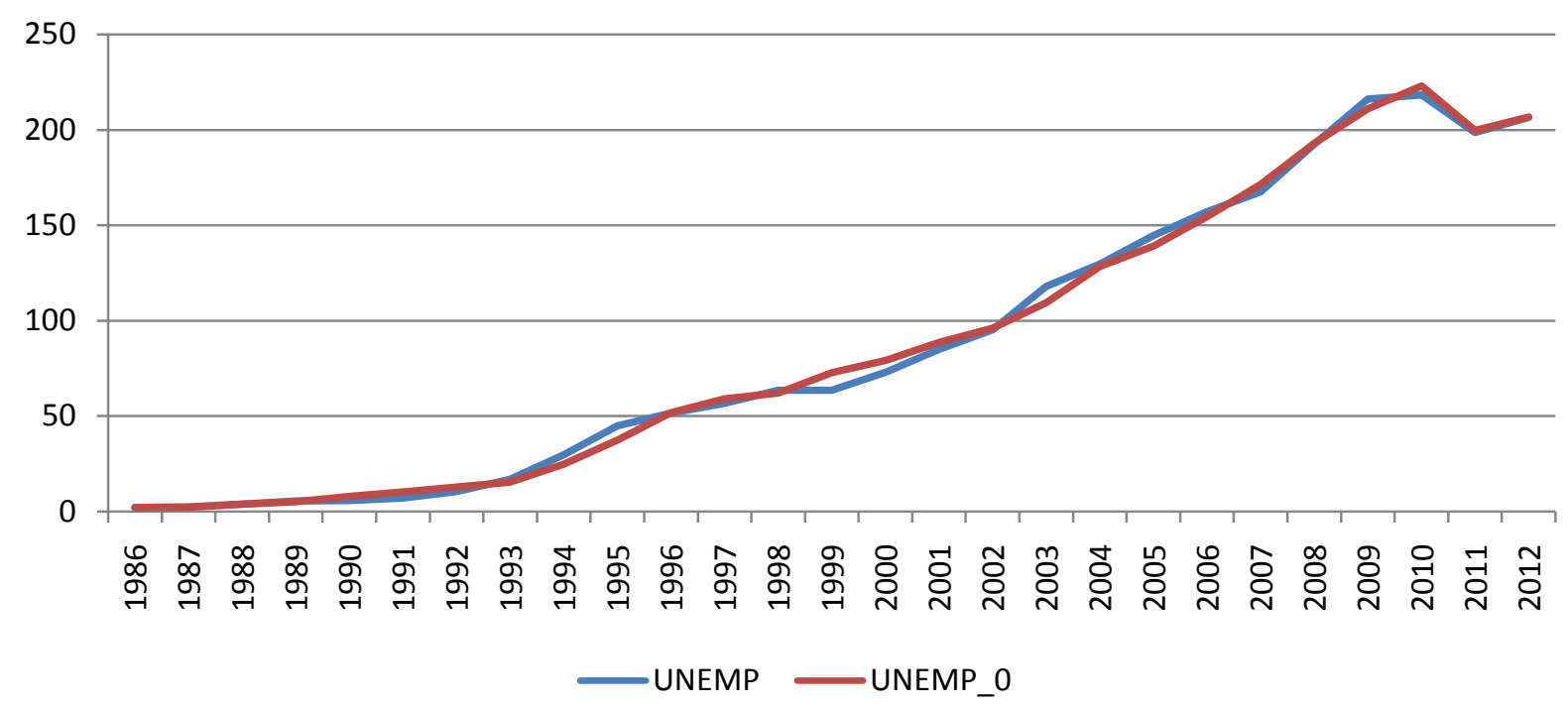

Tracking of Simulated Value of EXR
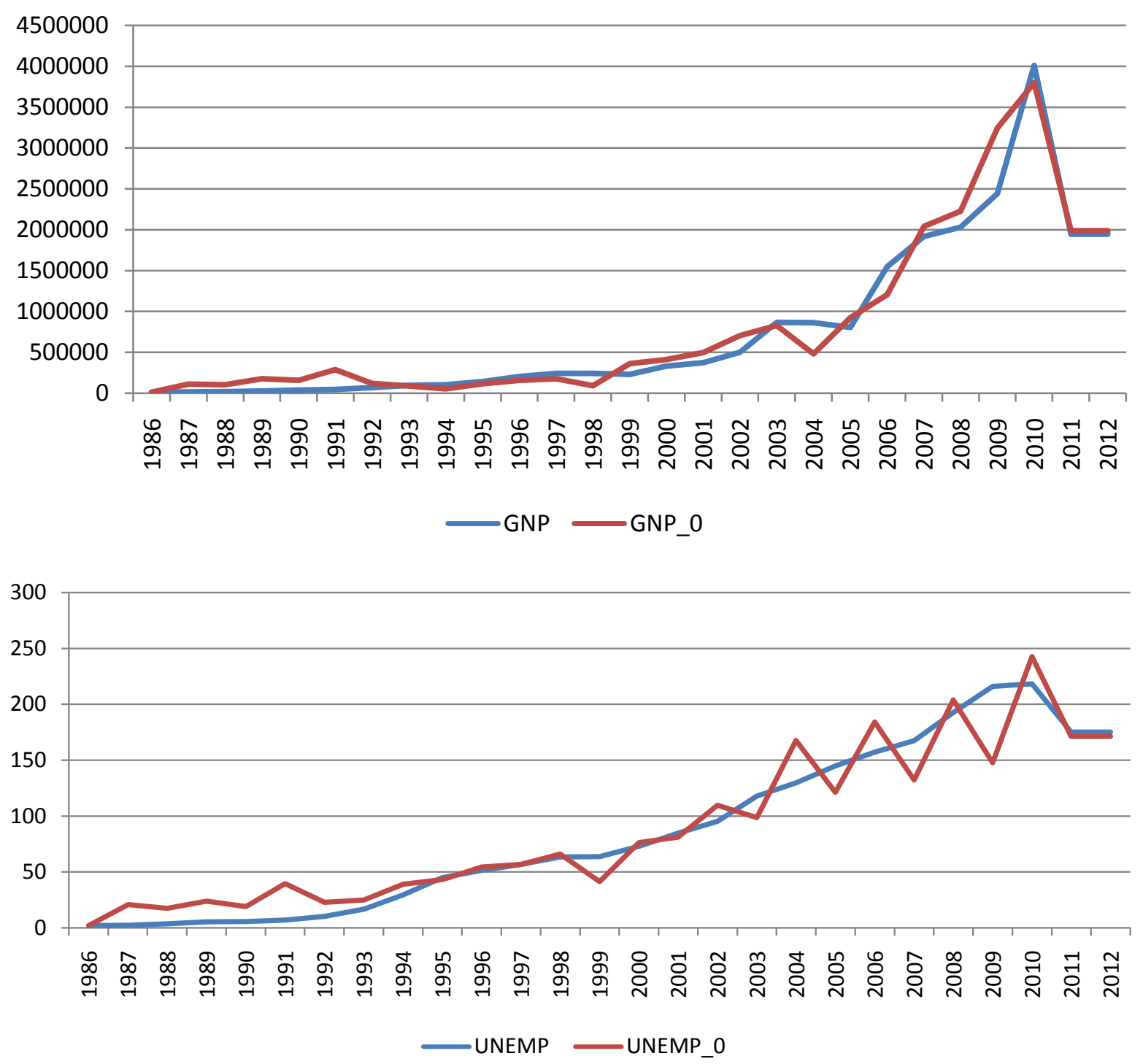
Tracking of Simulated Value of MCAP
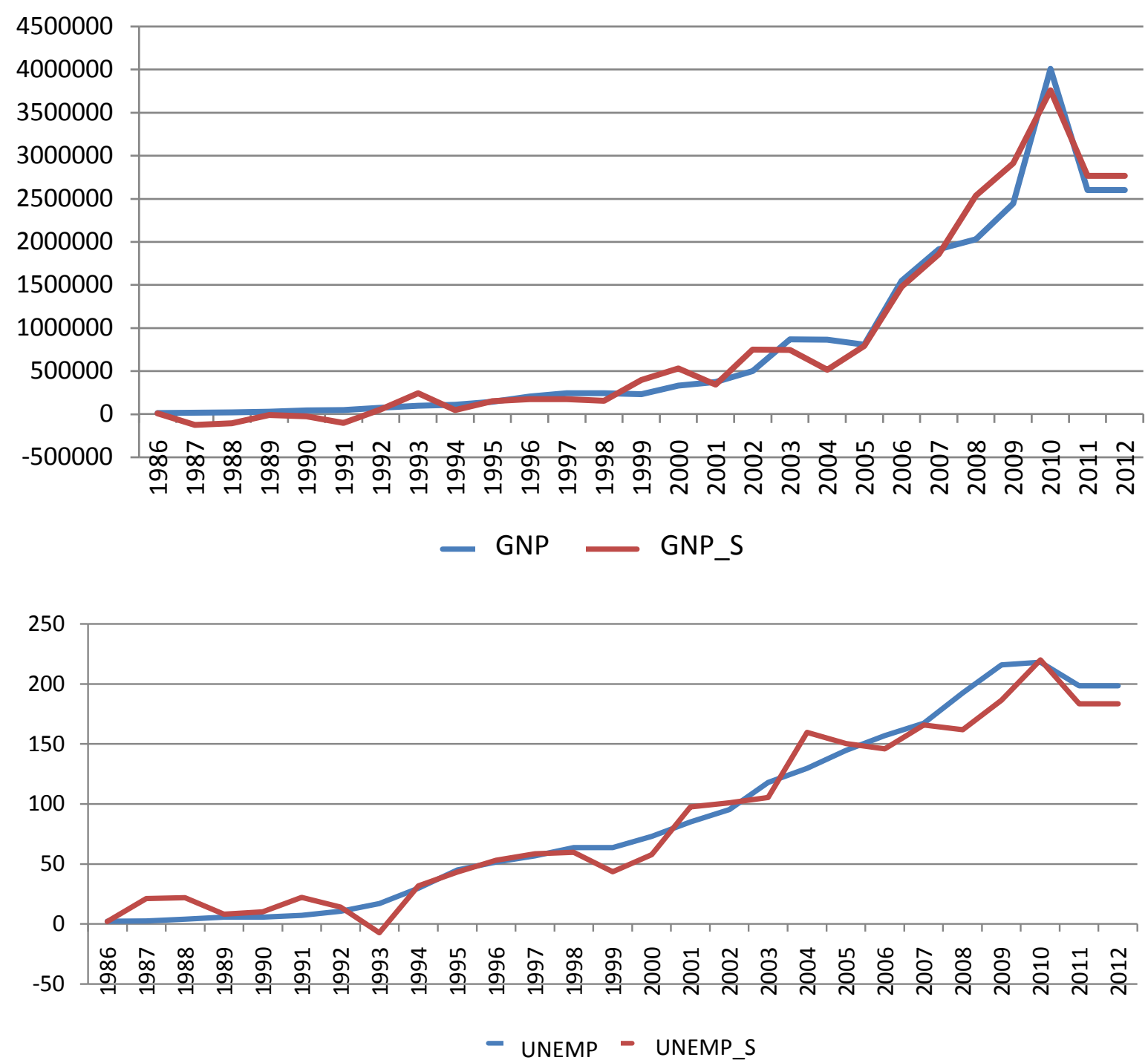

Scientific Research Publishing

Submit or recommend next manuscript to SCIRP and we will provide best service for you:

Accepting pre-submission inquiries through Email, Facebook, LinkedIn, Twitter, etc.

A wide selection of journals (inclusive of 9 subjects, more than 200 journals)

Providing 24-hour high-quality service

User-friendly online submission system

Fair and swift peer-review system

Efficient typesetting and proofreading procedure

Display of the result of downloads and visits, as well as the number of cited articles

Maximum dissemination of your research work

Submit your manuscript at: http://papersubmission.scirp.org/

Or contact ojbm@scirp.org 